\title{
Challenges and Benefits of Transplanting Large Trees: An Introduction to the Workshop
}

\author{
Michael A. Arnold ${ }^{1}$
}

ADDITIONAL INDEX WORDS. arboriculture, landscape establishment, landscape maintenance, post-transplant establishment, tree establishment, tree mortality, urban forestry

Summary. Across horticultural crops the trend is to transplant larger plants to achieve the intended landscape effects or to produce the desired yield without the long wait associated with direct seeding or small transplant technology. Consumers want immediate gratification (a landscape design that produces the desired aesthetics without the wait for plants to grow to mature sizes). This trend extends from the use of large herbaceous plants for instant landscape color, transplanting of vegetable plants already in fruit to the home garden for early yield, to transplanting larger shrubs and trees to effect the impression of an established landscape. This trend logically culminates in the transplanting of large, mature specimen trees to create the appearance of a fully mature landscape. This workshop will explore the potential benefits of this approach and the challenges associated with successful transplanting of large trees.

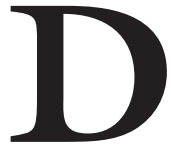

EMAND FOR INSTANT LANDSCAPES. In

today's time-oriented society, con-

sumers want instant gratification.

The landscape and nursery industries are no stranger to this phenomenon, with the trend toward marketing larger stock extending from the bedding plant and color sectors to woody plants. Examples of such demand include the sales of large color bowls and patio containers for instant pockets of color (Starman and Eixmann, 2003) to the marketing of containers with summer squash (Cucurbita pepo var. melopepo), tomatoes (Lycopersicon lysopersicum), peppers (Capsicum annuum), and other vegetables with immature or even mature fruit ready to deliver "home grown vegetables" to the impatient consumer (Branch-Smith Publ., 1998). The logical conclusion of this instant landscape concept is the transplanting of large mature shade or specimen trees. While this demand has encompassed pursuits as exotic

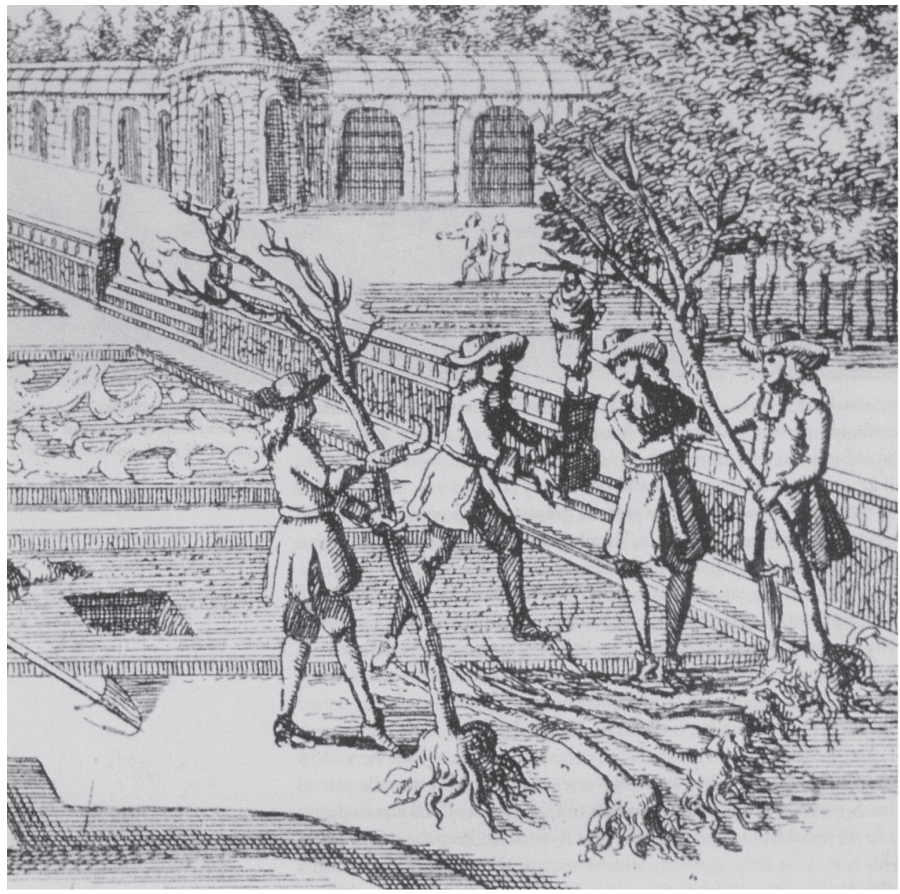

Fig. 1. Transplanting of bare-root fruit trees in the 1700s (image courtesy of Lyons Press, Guilford, Conn.). as moving an intact 24.4 -m-tall $(80 \mathrm{ft})$ dead european beech (Fagus sylvatica) tree for use in a motion picture production (Keen, 1980), most interest is centered around moving live, large trees for use in high-value commercial properties (Environmental Design, 1996; Mecklenburg, 1990).

DEVELOPMENT OF LARGE TREE TRANSPLANT TECHNOLOGY. Starting with larger transplanted stock is not a new idea. As early as the 1600s, various species of large bare-root deciduous fruit trees (Fig. 1), as well as large container-grown citrus (Citrus spp.), were transplanted to the garden to hasten fruit yields (Huxley and Michael, 1998). Attempts at moving large shade trees were reported in the early

${ }^{1}$ Associate Professor of Landscape Horticulture, Dept. of Horticultural Sciences, Mail Stop 2133, Texas A\&M University, College Station, TX 778432133. E-mail: ma-arnold@tamu.edu

Mention of a trademark, proprietary product, or vendor does not constitute a guarantee or warranty of the product by the author, the Texas A\&M University, or the Texas Agricultural Experiment Station, and does not imply its approval to the exclusion of other products or vendors that also may be suitable. 


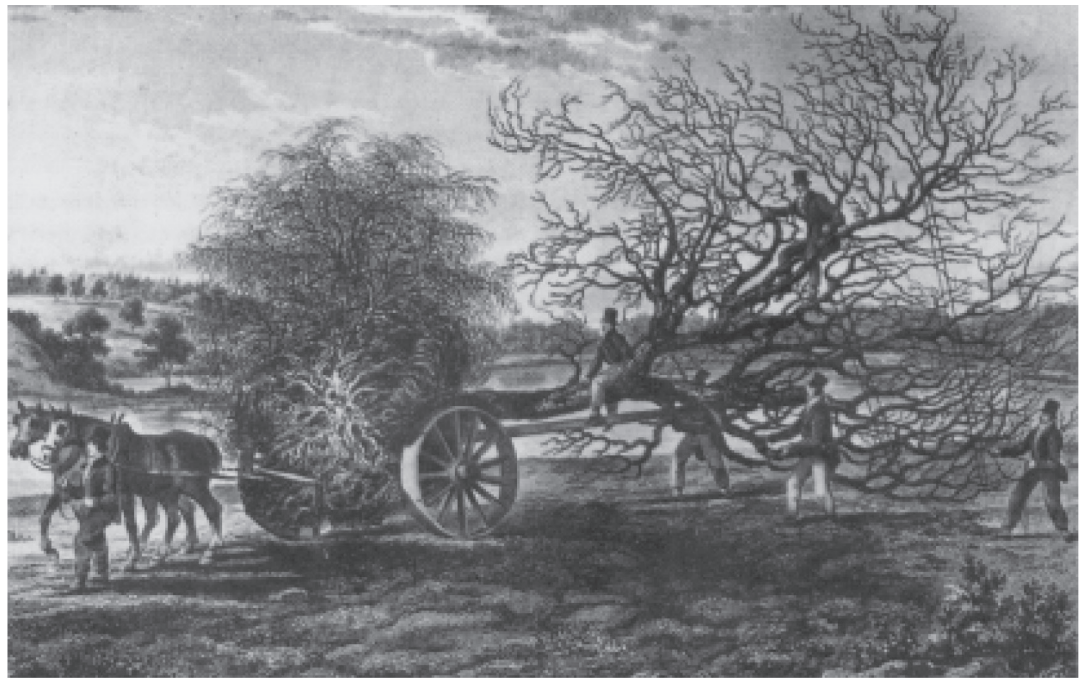

Fig. 2. Large tree transplanting in $\mathbf{1 8 2 3}$ was essentially bare-root transplanting on a grand scale (image courtesy of Lyons Press, Guilford, Conn.).

1800s (Fig. 2), but the existing technology of hand labor and horse-drawn equipment limited success as these trees were effectively bare-root transplants (Huxley and Michael, 1998). Although technologies continued to improve with better techniques, such as the use of slings and pulleys for maintaining root ball integrity (Fig. 3), limitations including hand labor, rudimentary transport equipment, and the quality of road surfaces continued to limit the size of trees that could feasibly be moved (Huxley and Michael, 1998) until the mid-20th century. The advent and application of hydraulic equipment and mobile cranes (Fig. 4) greatly decreased the costs and increased the likelihood of success associated with transplanting larger specimen size trees, with up to $203.2-\mathrm{cm}$-diameter ( 80 inches) root balls. These techniques were first reported in Europe (Forestry and British Timber, 1979; Newman, 1975, 1982; Stanley, 1979; Volgmann, 1979; Zima and Grushanskii, 1978) and have since spread to the U.S. and other countries.

Demand for quality aesthetics in high-value resort developments, such as Disneyland Resort (Anaheim, Calif.), Epcot Center (Lake Buena Vista, Fla.), Busch Gardens (Tampa, Fla., and Williamsburg, Va.), etc., where cost concerns are less of a factor have helped to facilitate the development of methods for moving very large specimen trees (Mecklenburg, 1990). Demand for larger transplant stock has become a part of government policy over the years in countries as diverse as East Germany (Gruneberg, 1974) and the U.S. (Murphy, 2003). The number of larger trees that are being transplanted has increased dramatically over the years. For example, the Texas Department of Transportation has planted 30,000 to 40,000 trees annually over the past 5 years in Houston,

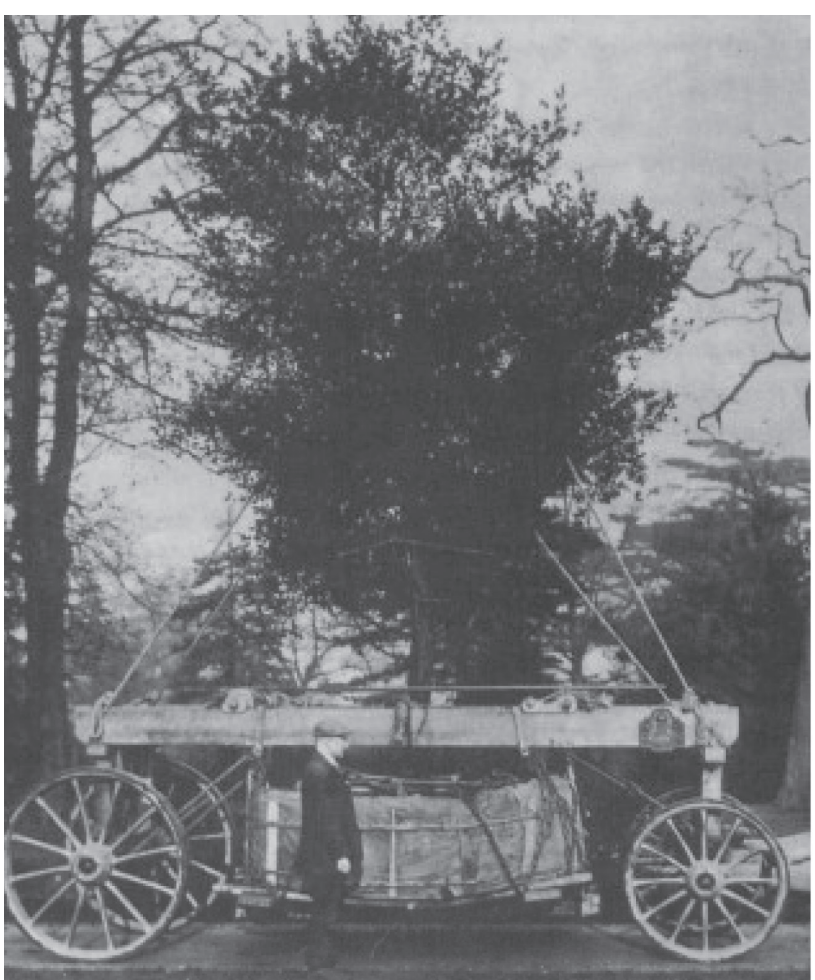

Fig. 3. Moving large trees in the early 20th century had improved, but was still hindered by root ball sizes that could be moved via pulleys and limited transportation technology (image courtesy of Lyons Press, Guilford, Conn.).

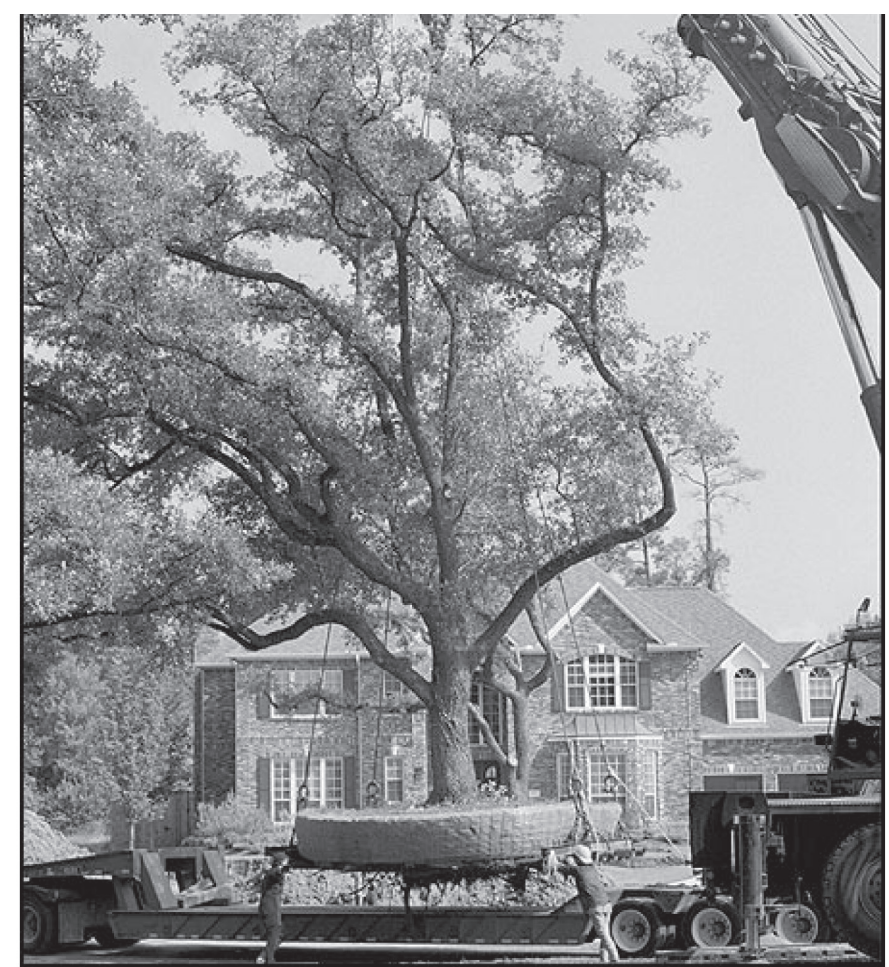

Fig. 4. Modern hydraulic equipment, cranes, and tractor trailer rigs have facilitated movement of fully mature trees (image courtesy of Environmental Design, Tomball, Texas). 
Fig. 5. Shoot growth indices of bitterweed grown in 1208 six-packs [volume $=0.06 \mathrm{~L}(0.016 \mathrm{gal}) ; \mathrm{y}=150-259 \mathrm{x}+$ $\left.138 x^{2} ; R^{2}=0.99\right] ; 606$ six-packs [volume $=0.13 \mathrm{~L}(0.034$ gal); $\left.\mathrm{y}=880-996 \mathrm{x}+438 \mathrm{X}^{2} ; R^{2}=0.99\right]$; jumbo 606 sixpacks [volume $=0.16 \mathrm{~L}(0.042 \mathrm{gal}) ; \mathrm{y}=1088-1210 \mathrm{x}+$ $\left.468 \mathrm{x}^{2} ; R^{2}=0.98\right]$; or individual $10.2-\mathrm{cm}$-diameter (4 inches) containers $[$ volume $=0.51 \mathrm{~L}(0.135 \mathrm{gal}) ; \mathrm{y}=276-421 \mathrm{x}$ $\left.+420 \mathrm{x}^{2} ; R^{2}=0.98\right]$ after transplanting to landscape beds in College Station, Texas. Symbols represent means $( \pm \mathrm{SE})$ of 36 observations and regression equations are significant at $P \leq 0.01\left(1 \mathrm{~cm}^{3}=0.06 \mathrm{inch}^{3}\right)$.

Texas, in anticipation of Super Bowl XXXVIII (Murphy, 2003). Although a wide range of sizes were planted, trees were a minimum of 2.1 to $3.0 \mathrm{~m}$ ( 7 to $10 \mathrm{ft}$ ) tall and included over 1000 palms (family Aecaceae) (Murphy, 2003).

UNANSWERED QUESTIONS. Now the question is not whether large trees can be moved but, rather, how can they can be transplanted most effectively? While it has long been recognized that controlling the water balance in transplanted trees is critical to successful transplant establishment (Kozlowski and Davies, 1975), many other factors are also known to affect establishment. Many of these factors affecting transplant establishment are not fully understood for conventional size transplants, much less what their implications are in association with moving large trees (Newman, 1975). Mechanical issues associated with engineering constraints of digging, lifting, and hauling trees must be defined. This may require interaction with regulatory authorities for transporting large trees on roads and highways and for clearance of utility lines. Physiological issues related to root regeneration potential, season of transplanting, and the life cycle stage of the trees being transplanted will need to be investigated. Devitt et al. (1995) found that plant size was a critical component in measuring evapotranspiration for several arid region trees to schedule efficient irrigation applications.

The bedding plant industry has moved to larger containers for annual and perennial color plants in recent years to capitalize on more rapid realization of a landscape's display potential. For instance, bitterweed (Helenium amarum) from the same seed flat grew only slightly larger in larger containers during nursery production, but these growth advantages were compounded throughout the growing season in the landscape (Fig. 5). Research with using large tree transplants has not al- ways documented such benefits, as the resulting transplant shock can last longer with larger than with smaller trees (Lauderdale et al., 1995). Interdisciplinary efforts with agricultural engineers, civil engineers, urban foresters, horticulturists, plant pathologists, entomologists, and agricultural economists will be necessary to assess the feasibility and cost effectiveness of various management techniques applied to moving large trees in a variety of climates. As the industry progresses and more trees are produced in nurseries specifically for sale as large specimens, research will be needed on production practices for various stock types.

The objectives of this workshop were to summarize the current research related to transplanting various classes of specimen trees; document the potential benefits of transplanting specimen trees for immediate landscape effects; and identify the challenges associated with establishment and long-term survival of large transplanted trees.

\section{Literature cited}

Branch-Smith Publishing Co. 1998. Plant picks: Container vegetables. Branch-Smith Publ., Fort Worth, Texas. 7 Dec. 2003. <http://www.greenbeam.com/features/ plant110998.stm>.

Devitt, D.A., D.S. Neuman, D.C. Bowman, and R.L. Morris. 1995. Water use of landscape plants grown in an arid environment. J. Arboricult. 21:239-245.

Environmental Design, Inc. 1996. Treemendous transplanting. Environmental Design, Inc., Tomball, Texas. 8 Dec. 2003. <http://www.instantshade.com/>.

Forestry and British Timber. 1979. New equipment for the forester. For. Brit. Timber $8: 6,38$.

Gruneberg, H. 1974. Preparatory treatment and transplanting of large trees for the landscaping of residential areas: A task assigned to the state forest enterprises by the E. German government. Beitrate-fur-die-Forstwirtschaft 8:4, 193-196.

Huxley, A. and M. Michael. 1998. An illustrated history of gardening. Lyons Press, Guilford, Conn.

Keen, I.J. 1980. An unusual contract or how to approach Heaven's Gate. Arboricult. J. 4(2):141-146.

Kozlowski, T.T. and W.J. Davies. 1975. Control of water balance in transplanted trees. J. Arboricult. 1:1-10

Lauderdale, D.M., C.H. Gilliam, D.J. Eakes, G.J. Keever, and A.H. Chappelka. 1995. Tree transplant size influences post-transplant growth, gas exchange, and leaf water potential of 'October Glory' red maple. J. Environ. Hort. 13:178-181.

Mecklenburg, R.A. 1990. Moving large specimen trees with minimal shock. Proc. Fla. State Hort. Soc. 103:368-370.

Murphy, B. 2003. Ugly? Leaders see the blight, freeway landscaping part of Super Bowl plan. Houston Chronicle 102(280): Al, Al0-11.

Newman, C.J. 1975. Semi-mature tree transplanting-One man's view of techniques today. Arboricult. J. 2(8):324-329.

Newman, C.J. 1982. English techniques in large tree transplanting. J. Arboricult. 8:90-93.

Starman, T. and K. Eixmann. 2003. Container gardens. 7 Dec. 2003. <http://aggie-horticulture.tamu.edu/floriculture/containergarden/index.html>.

Stanley, J. 1979. Tree lifting: Making new machines to do the old jobs. Gardener's Chronicle and Hort. Trade J. (GC\&HTJ) 186(20):22-23.

Volgmann, W. 1979. Sequence of operations for transplanting older trees. AllgemeineForstzeitschrift 37:1003-1004.

Zima, I.M. and O.A. Grushanskii. 1978. Machine for transplanting large trees. LesnoeKhozyaistvo 6:62-64. 